\title{
Analisis Biaya Minimal dan Efektifitas Terapi Diabetes Melitus Tipe 2 di RSUD Panglima Sebaya Paser
}

\author{
Norhalimah $^{1, \dagger}$, Risna Agustina ${ }^{1}$, Rolan Rusli ${ }^{1,2, \sharp}$ \\ ${ }^{1}$ Laboratorium Penelitian dan Pengembangan Kefarmasian "Farmaka Tropis", \\ Fakultas Farmasi, Universitas Mulawarman, Samarinda, Indonesia \\ †Email: norhalimahibrahim@gmail.com \\ ${ }^{2}$ Kelompok Bidang Ilmu Kimia Farmasi, Fakultas Farmasi, \\ Universitas Mulawarman, Samarinda, Indonesia \\ *Email: rolan@farmasi.unmul.ac.id
}

\begin{abstract}
ABSTRAK
Diabetes melitus adalah suatu penyakit yang memerlukan terapi selama hidupnya sehingga membutuhkan biaya yang cukup besar untuk terapi pengobatannya. Tujuan penelitian ini adalah untuk mengetahui obat antidiabetik dengan biaya minimal dan efektif di Rumah Sakit Umum Daerah Panglima Sebaya Paser. Penelitian dilakukan secara retrospektif terhadap catatan rekam medis. Hasil penelitian terhadap 95 pasien menunjukkan bahwa obat antidiabetik yang paling banyak digunakan yaitu kombinasi insulin novorapid dengan levemir dan novorapid engan ezelin. Penggunaan obat yang efektif pada terapi diabetes melitus adalah insulin ezelin kombinasi dengan novorapid dengan nilai ACER Rp $22.984,00$.
\end{abstract}

Kata Kunci: Diabetes melitus; Cost Minimization Analysis (CMA); Cost Effectivenes Analysis (CEA)

DOI: https://doi.org/10.25026/mpc.v7i1.294

\section{PENDAHULUAN}

Di masa kini jumlah penderita penyakit degeneratif cenderung lebih meningkat secara signifikan. Salah satu penyakit degeneratif adalah Diabetes Melitus (DM). Diabetes melitus adalah suatu gangguan metabolisme yang secara genetis dan klinis yang ditandai dengan hiperglikemia akibat adanya kelainan metabolisme karbohidrat, lemak, dan protein. Penyakit ini juga disebabkan oleh pankreas yang tidak lagi dapat memproduksi insulin dengan jumlah yang cukup atau tubuh tidak dapat menggunakan insulin yang diproduksinya $[1,12]$.

Menurut The International Diabetes Federation (IDF) (2015), bahwa penderita diabetes melitus meningkat mencapai 415 juta yang diperkirakan akan terus meningkat hingga $55 \%$ menjadi 642 juta. Menurut data International Diabetes Federation (IDF) (2015) bahwa penderita diabetes di Indonesia diperkirakan mencapai 10 juta sehingga menempati urutan ke-7 penderita diabetes melitus tertinggi di dunia. Berdasarkan data Riskesdas (2018), sebanyak 10,9\% penduduk 
Indonesia yang berusia $\geq 15$ tahun menderita diabetes melitus. Prevalensi diabetes melitus tertinggi yang didiagnosis terdapat di daerah DKI Jakarta $(3,4 \%)$, Kalimantan Timur $(3,0 \%)$ DI Yogyakarta $(2,9 \%)$, Sulawesi Utara $(2,8 \%)[2,11]$.

Banyaknya pasien diabetes melitus mengakibatkan tingginya kebutuhan obat antidiabetik, sehingga penggunaan obat antidiabetik ini bervariasi tergantung tingkat keparahan pasien. Tingginya kebutuhan obat antidiabetik disebabkan karena pasien diabetes melitus memerlukan terapi seumur hidupnya sehingga membutuhkan biaya yang cukup besar untuk terapi pengobatannya. Oleh karena itu diperlukan pemikiran-pemikiran khusus dalam peningkatan efisiensi atau penggunaan dana secara lebih rasional. Farmakoekonomi sebagai suatu wadah untuk meningkatkan efisiensi dan mobilisasi sumber dana yang dapat dipergunakan untuk membantu mengembangkan pemikiran-pemikiran khusus tanpa mengabaikan aspek-aspek sosial dari sektor kesehatan itu sendiri. Penelitian mengenai farmakoekonomi yang dilakukan dengan menganalisis biaya obat yang digunakan pada saat proses terapi farmakologi penyakit diabetes melitus di daerah Paser Kalimantan Timur.

\section{METODE PENELITIAN}

Jenis penelitian ini adalah penelitian non eksperimental dengan desain penelitian yang bersifat deskriptif. Pengambilan data dilakukan secara retrospektif menggunakan catatan rekam medis pasien diabetes melitus tipe 2 dengan rentang usia $\geq 15$ tahun yang dirawat inap di RSUD Panglima Sebaya Paser periode 2017. Data pasien yang diambil adalah data pasien dengan data catatan medis yang lengkap dan keluar rumah sakit dalam keadaan cukup baik dan sehat. Perincian biaya obat yang digunakan pasien diperoleh di bagian kefarmasian untuk dianalisis CMA (Cost Minimization Analysis) dan CEA (Cost Efectivenes Analysis) penggunaan obatnya.

\section{HASIL DAN PEMBAHASAN}

\section{Gambaran karakteristik pasien}

Gambaran karakteristik pasien dalam penelitian ini meliputi jenis kelamin, usia dan pekerjaan tersaji dalam Tabel 1. Berdasarkan jenis kelamin dari 95 pasien yang memenuhi kriteria inklusi terdapat 32 pasien (34\%) laki-laki dan 63 pasien $(66 \%)$ perempuan. Hal ini disebabkan oleh perbedaan aktivitas fisik antara laki-laki dan perempuan, dimana diketahui bahwa aktivitas fisik laki-laki lebih banyak dibandingkan dengan perempuan. Sehingga proses pengambilan glukosa pada tubuh laki-laki lebih besar dan menyebabkan sedikitnya kemungkinan untuk terjadi hiperglikemia [3].

Tabel 1. Gambaran distribusi pasien DM Tipe 2 rawat inap di RSUD Panglima Sebaya Paser

\begin{tabular}{cc}
\hline Karakteristik & Persentase (\%) \\
\hline Jenis Kelamin & 34 \\
Laki-laki & 66 \\
Perempuan & \\
\hline Usia & 3 \\
21 - 30 Tahun & 6 \\
31 - 40 Tahun & 37 \\
41 - 50 Tahun & 31 \\
51 - 60 Tahun & 20 \\
61 - 70 Tahun & 3 \\
71 - 80 Tahun & \\
\hline Lama Rawat Inap & 64 \\
1 - 5 Hari & 26 \\
6 - 10 Hari & 9 \\
11 - 15 Hari & \\
\hline
\end{tabular}

Pasien dikelompokkan berdasarkan usia untuk mengetahui pada rentang usia berapa kasus diabetes tipe 2 ini mengalami peningkatan. Dari hasil 
pengelompokkan tersebut dapat diketahui bahwa pasien diabetes mellitus tipe 2 mengalami peningkatan pada rentang usia 41-50 tahun (37\%), hal ini telah sesuai dengan pernyataan dari Dipiro dan ADA bahwa faktor resiko terjadinya diabetes melitus tipe 2 paling banyak terjadi pada usia diatas 40 tahun[4,5]. Urutan kedua kejadian diabetes melitus terbanyak yaitu pada rentang usia 51-60 tahun (31\%), kemudian yang ketiga pada rentang usia 61-70 tahun (20\%). Penuaan dapat mempengaruhi hormon yang mengatur metabolisme, reproduksi dan fungsi tubuh yang lain termasuk mengurangi sensitivitas sel beta pankreas untuk mensekresikan insulin[6]. Sehingga berkurangnya sekresi insulin dapat menyebabkan terjadinya hiperglikemia. Selain itu, dapat pula dikarenakan oleh perubahan pola makan dan kurangnya aktivitas fisik seperti berolahraga [3].

Pengelompokan pasien berdasarkan lama rawat inap dibagi menjadi 3 yaitu pada 1-5 hari, 6-10 hari dan 11-15 hari. Sehingga pada Tabel 1 menunjukan bahwa pasien paling banyak pada rentang 1-5 hari (64\%), pasien terbanyak kedua yaitu pada rentang 6-10 hari $(26 \%)$ dan yang ketiga yaitu pada rentang 11-15 hari (9\%). Hal ini dapat mempengaruhi biaya yang akan dikeluarkan oleh pasien.

\section{Gambaran penggunaan obat antidiabetik}

Keteraturan obat antidiabetik pada pasien diabetes melitus tipe 2 sangatlah penting karena hal ini diperlukan untuk mengurangi dan menjaga kadar glukosa darah pasien agar resiko terjadinya komplikasi dapat dikurangi serta untuk meningkatkan kualitas hidup pasien diabetes melitus tipe 2 .

Gambaran distribusi penggunaan obat antidiabetik dikelompokkan menjadi 4 yaitu insulin tunggal, kombinasi dua insulin, kombinasi insulin dan antidiabetik oral, dan kombinasi dua insulin dan satu antidiabetik oral. Pada
Tabel 2 dapat diketahui bahwa obat antidiabetik yang paling banyak digunakan adalah kombinasi dua insulin yaitu novorapid dengan ezelin sebanyak 22 pasien (23\%) dan novorapid dengan levemir sebanyak 43 pasien (45\%).

Tabel 2. Gambaran distribusi penggunaan obat antidiabetik

\begin{tabular}{lc}
\hline \multicolumn{1}{c}{ Antidiabetik } & $\begin{array}{c}\text { Persentase } \\
(\%)\end{array}$ \\
\hline Insulin Monoterapi & 11 \\
$\mathrm{~N}$ & 3 \\
$\mathrm{E}$ & \\
\hline Kombinasi 2 Insulin & 23 \\
$\mathrm{~N}+\mathrm{E}$ & 45 \\
$\mathrm{~N}+\mathrm{L}$ & \\
\hline Kombinasi Insulin \& ADO & 2 \\
$\mathrm{E}+\mathrm{M}$ & 1 \\
$\mathrm{E}+\mathrm{G}$ & 5 \\
$\mathrm{~N}+\mathrm{M}$ & 3 \\
$\mathrm{~N}+\mathrm{G}$ & \\
\hline Kombinasi 2 Insulin \& $1 \mathrm{ADO}$ & \\
$\mathrm{N}+\mathrm{E}+\mathrm{G}$ & 1 \\
$\mathrm{~N}+\mathrm{E}+\mathrm{M}$ & 4 \\
$\mathrm{~N}+\mathrm{L}+\mathrm{M}$ & 1 \\
\hline
\end{tabular}

Keterangan: $\mathrm{ADO}=$ antidiabetik oral, $\mathrm{N}=$ Novorapid, $\mathrm{E}=$ Ezelin, $\mathrm{L}=$ Levemir, $\mathrm{M}=$ Metformin dan $\mathrm{G}=$ Glimepirid

Insulin novorapid merupakan jenis rapid acting insulins yang digunakan untuk menurunkan glukosa darah dengan cepat melalui aktivasi reseptor insulin dan menurunkan produksi glukosa di hati[1]. Insulin jenis ini memungkinkan untuk menggantikan insulin secara fisiologis pada saat makan dikarenakan kerjanya yang cepat dan insulin ini dapat diberikan sebelum makan tanpa mengganggu kontrol glukosa [7]. Sedangkan ezelin dan levemir merupakan insulin long acting, yang akan meregulasi metabolisme glukosa. Insulin dan analognya dapat menurunkan kadar glukosa darah dengan 
cara merangsang pengambilan glukosa di perifer, terutama oleh otot rangka dan lemak, dan dengan menghambat produksi glukosa hati [8].

\section{Biaya terapi diabetes melitus}

Diabetes melitus adalah suatu penyakit yang membutuhkan pengobatan selama hidupnya, oleh karena itu diperlukan biaya yang cukup besar untuk mengobati atau mengurangi penyakit tersebut. Keteraturan obat antidiabetik pada pasien DM tipe 2 merupakan suatu hal yang cukup penting untuk mengatur pola hidup pasien. Terapi yang diberikan pada pasien biasanya bervariasi tergantung bagaimana kondisi tubuh. Pada penelitian ini terapi yang paling banyak digunakan adalah terapi insulin yaitu sekitar 82\% (Tabel 3). Terapi insulin memiliki biaya yang lebih besar dibandingkan dengan terapi oral. Berdasarkan data harga obat yang diperoleh dari instalasi farmasi RSUD Panglima Sebaya Paser, diperoleh harga insulin novorapid $\mathrm{Rp}$ 87.000,00/pen, ezelin $\mathrm{Rp} \mathrm{83.950,00/cartridge,} \mathrm{levemir}$ Rp 83.950,00/pen, metformin 500 mg Rp 103,00/tablet dan glimepirid $2 \mathrm{mg} \mathrm{Rp}$ 207,00/tablet. Pada biaya terapi diabetes melitus dipengaruhi oleh lama rawat inap pasien, dimana semakin lama pasien dirawat di rumah sakit maka semakin meningkatkan biaya yang dikeluarkan pasien tersebut.

Tabel 3. Gambaran biaya rata-rata terapi diabetes melitus

\begin{tabular}{cccc}
\hline Antidiabetik & Persentase (\%) & LOS (Hari) & Rata-rata biaya (Rp) \\
\hline Insulin Monoterapi & & & \\
N & 11 & 7 & Rp1.236.520,00 \\
E & 3 & 7 & Rp921.942,00 \\
\hline Kombinasi 2 Insulin & & & \\
N + E & 23 & 6 & Rp1.312.483,77 \\
N + L & 45 & 6 & Rp1.148.798,53 \\
\hline Kombinasi Insulin \& ADO & & & \\
E + M & 2 & 4 & Rp1.497.768,00 \\
E + G & 1 & 3 & Rp594.732,00 \\
N + M & 5 & 5 & Rp1.114.177,67 \\
N + G & 3 & 4 & Rp1.257.958,00 \\
\hline Kombinasi 2 Insulin \& 1 ADO & & Rp1.089.828,25 \\
N + E + G & 1 & 6 & Rp1.450.384,00 \\
N + E + M & 4 & 6 &
\end{tabular}

Keterangan: $\mathrm{ADO}=$ antidiabetik oral, $\mathrm{N}=$ Novorapid, $\mathrm{E}=$ Ezelin, $\mathrm{L}=$ Levemir, $\mathrm{M}=$ Metformin dan $\mathrm{G}=$ Glimepirid

Berdasarkan Tabel 3, obat yang diberikan dikelompokkan menjadi insulin tunggal, kombinasi dua insulin, kombinasi insulin dengan antidiabetik oral, dan kombinasi dua insulin dengan antidiabetik oral. Pada kelompok insulin tunggal terdapat insulin novorapid dan ezelin, dimana terdapat $11 \%$ pasien yang menggunakan novorapid dan 3\% pasien menggunakan ezelin. Rata-rata biaya yang dikeluarkan pasien yang menggunakan novorapid yaitu sebesar Rp1.236.520,00. Sedangkan untuk penggunaan ezelin yaitu sebesar 
Rp921.942,00. Dengan demikian, dilihat dari segi biaya, maka penggunaan ezelin lebih minimal dibandingkan dengan novorapid

Berdasarkan pada kelompok kombinasi dua insulin terdapat kombinasi antara insulin novorapid dengan ezelin dan novorapid dengan levemir. Dimana diketahui ezelin dan levemir berasal dari kelas terapi yang sama. Biaya rata-rata penggunaan obat novorapid dengan ezelin (23\% pasien) adalah Rp1.312.483,00. Sedangkan biaya ratarata penggunaan novorapid dengan levemir $(45 \%$ pasien) adalah Rp1.148.798,00. Sehingga pada kelompok ini dapat diketahui bahwa lebih minimal pada penggunaan novorapid dengan levemir.

Pada kelompok kombinasi insulin dengan antidiabetik oral yaitu biaya ratarata penggunaan obat novorapid dengan metformin (5\% pasien) adalah Rp1.060.832,40. Biaya rata-rata penggunaan obat novorapid dengan glimepirid (3\% pasien) adalah Rp1.114.177,00. Pada terapi ezelin dengan metformin (2\% pasien), biaya rata-rata penggunaan obatnya sebesar Rp1.497.768,00. Sedangkan untuk terapi ezelin dengan glimepirid (1\% pasien), biaya rata-rata penggunaan obatnya sebesar Rp594.732,00. Sehingga dapat disimpulkan bahwa berdasarkan penggunaan terapi insulin kombinasi dengan antidiabetik oral yang memiliki biaya yang paling minimal adalah pada pengunaan ezelin dengan glimepirid.

Kelompok terapi yang terakhir yaitu kombinasi dua insulin dengan antidiabetik oral. Rata-rata biaya Pengunaan novorapid dengan ezelin dan metformin (4\% pasien) sebesar Rp1.089.828,00. Penggunaan novorapid dengan ezelin dan glimepirid untuk satu pasien memiliki total biaya sebesar Rp1.257.958,00. Sedangkan rata-rata biaya pada penggunaan novorapid dengan levemir dan metformin ( $1 \%$ pasien) sebesar Rp1.450.384,00. Sehingga berdasarkan data tersebut dapat diketahui bahwa penggunaan terapi yang paling minimal untuk kelas terapi kombinasi 2 insulin dengan antidiabetik oral yaitu pada terapi novorapid dengan ezelin dan metformin.

\section{Efektivitas terapi diabetes melitus}

Gambaran mengenai efektivitas suatu antidiabetik pada pasien diabetes melitus dapat dilihat dari kualitas hidup pasien dan nilai penurunan GDS (gula darah sewaktu) pada setelah pemberian terapi intervensi $[9,10]$. Penurunan GDS pasien diabetes melitus lebih spesifik penurunannya pada penggunaan insulin karena GDS akan lebih mudah untuk dikontrol penurunannya, berbeda halnya jika menggunakan antidiabetik oral dimana kombinasi insulin dengan antidiabetik oral dapat meningkatkan terjadinya hipoglikemia pada pasien.

Tabel 4. Rata-rata Nilai ACER

\begin{tabular}{lc}
\hline \multicolumn{1}{c}{ Antidiabetik } & $\begin{array}{c}\text { Rata-rata } \\
\text { Nilai ACER }\end{array}$ \\
\hline Insulin Monoterapi & \\
$\mathrm{N}$ & $\mathrm{Rp} 11.453,00$ \\
$\mathrm{E}$ & $\mathrm{Rp} 1.047,00$ \\
\hline Kombinasi 2 Insulin & \\
$\mathrm{N}+\mathrm{E}$ & $\mathrm{Rp} 22.984,00$ \\
$\mathrm{~N}+\mathrm{L}$ & $\mathrm{Rp} 44.638,00$ \\
\hline Kombinasi Insulin \& ADO & \\
$\mathrm{E}+\mathrm{M}$ & $\mathrm{Rp} 696,00$ \\
$\mathrm{E}+\mathrm{G}$ & $\mathrm{Rp} 207,00$ \\
$\mathrm{~N}+\mathrm{M}$ & $\mathrm{Rp} 4.737,00$ \\
$\mathrm{~N}+\mathrm{G}$ & $\mathrm{Rp} 1.354,00$ \\
\hline Kombinasi 2 Insulin \& 1 ADO \\
$\mathrm{N}+\mathrm{E}+\mathrm{G}$ & $\mathrm{Rp} 1.062,00$ \\
$\mathrm{~N}+\mathrm{E}+\mathrm{M}$ & $\mathrm{Rp} 2.833,00$ \\
$\mathrm{~N}+\mathrm{L}+\mathrm{M}$ & $\mathrm{Rp} 1.641,00$ \\
\hline Keterangan: & \\
ADO= antidiabetik oral, & $\mathrm{N}=\mathrm{Novorapid}$, \\
E=Ezelin, L=Levemir, M=Metformin dan \\
G=Glimepirid
\end{tabular}




\begin{tabular}{c|c}
$\begin{array}{c}\text { Kuadran IV } \\
(\mathrm{N} ; \mathrm{N}+\mathrm{L} ;\end{array}$ & Kuadran I \\
$\mathrm{N}+\mathrm{N}+\mathrm{N}+\mathrm{M} ; \mathrm{N}+\mathrm{G} ;$ \\
& $\mathrm{N}+\mathrm{E}+\mathrm{M})$ \\
\hline & Kuadran II \\
Kuadran III & $(\mathrm{E} ; \mathrm{E}+\mathrm{M} ;$ \\
$(\mathrm{E}+\mathrm{G})$ & $\mathrm{N}+\mathrm{E} ; \mathrm{N}+\mathrm{E}+\mathrm{G})$
\end{tabular}

Gambar 1. Pembagian Kuadran Obat Keterangan:

$\mathrm{N}=$ Novorapid, $\mathrm{E}=$ Ezelin, L=Levemir, $\mathrm{M}=$ Metformin dan $\mathrm{G}=$ Glimepirid

Penilaian mengenai efektivitas terapi pasien diabetes melitus berupa GDS dibandingkan dengan biaya terapi obat antidiabetik dapat dilihat pada Tabel 4. Hasil efektivitas dinyatakan dalam ACER (Average Cost Effectiveness Ratio) yang bertujuan untuk membandingkan antara biaya obat antidiabetik yang digunakan selama terapi dengan penurunan GDS pasien. Nilai ACER rata-rata pada kelompok terapi insulin tunggal yaitu novorapid Rp11.453,00 dan ezelin Rp1.047,00, pada terapi kombinasi dua insulin yaitu novorapid dengan ezelin Rp22.984,00 dan novorapid dengan levemir Rp44.638,00, pada terapi kombinasi insulin dengan antidiabetik oral yaitu ezelin dengan metformin Rp696,00, ezelin dengan glimepirid Rp207,00, novorapid dengan metformin Rp4.737,00 dan novorapid dengan glimepirid Rp1.354,00, sedangkan untuk terapi kombinasi 2 insulin dengan antidiabetik oral yaitu novorpid dengan ezelin dan glimepirid Rp1.062,00, novorapid dengan ezelin dan metormin Rp2.833,00 dan novorapid dengan levemir dan metformin Rp1.641,00. Berdasarkan nilai ACER dan persentase kejadian penyakit diabetes melitus tipe 2 dapat disimpulkan bahwa terapi ezelin lebih dianjurkan karena insulin jenis ini lebih cost effective dibandingkan dengan terapi lainnya yang dapat dilihat pada Gambar 1. Selain itu rekomendasi obat yang akan diberikan untuk melengkapi terapi insulin jenis ezelin yaitu kombinasi dengan insulin novorapid. Hal ini terjadi karena jika terapi ezelin dikombinasikan dengan antidiabetik oral maka kemungkinan terjadinya hipoglikemia akan sangat besar. Oleh karena itu lebih direkomendasikan untuk mengkombinasikan insulin ezelin dengan novorapid karena selain memiliki discounted unit cost paling rendah pada kelompok terapi kombinasi 2 insulin, ezelin dengan novorapid ini akan lebih mudah untuk mengontrol glukosa darah.

\section{KESIMPULAN}

Karakteristik pasien berupa jenis kelamin dan usia dapat menjadi faktor resiko seseorang terkena penyakit diabetes melitus tipe 2 . Antidiabetik yang paling banyak digunakan oleh pasien diabetes melitus tipe 2 rawat inap di RSUD Panglima Sebaya Paser yaitu jenis kombinasi insulin sebesar $68 \%$. Analisis biaya minimal dan efektivitas terapi yang baik untuk diabetes melitus tipe 2 rawat inap yaitu, jenis kombinasi 2 insulin yaitu ezelin dengan novorapid dengan nilai ACER Rp 22.984,00. Sehingga dianjurkan untuk menggunakan antidiabetik jenis tersebut dilihat dari segi biaya dan keefektifannya.

\section{REFERENSI}

[1] Andayani, T.M.2006. Analisis Biaya Terapi diabetes melitus di rumah sakit Dr.Sardjito Yogyakarta.Fakultas farmasi, UGM Yogyakarta. Majalah Farmasi Indonesia 130-135.

[2] IDF.2015. International Diabetes Federation Anual Report High Quality Research and Policy Depelopment.

[3] Yulianti,Sri Rahayu, Alwiyah Mukaddas \& Inggrid Faustine.2014. Profil Pengobatan Pasien Diabetes Melitus Tipe 2 di Instalasi Rawat Inap RSUD Undata Palu Tahun 2012. Online Jurnal Of Nature 
Science. Vol 3(1):40-46 ISSN:23380950.

[4] American Diabetes Association. 2017. Standars Of Medical Care In Diabetes. The Journal Of linical And Applied Research And Education Vol.40 ISSN:0149-5992..

[5] Dipiro, J.T., Talbert, R.L., Yee, G.C., Matzke, G.R., Wells, B.G \& Posey, L.M. 2008. Pharmacotherapy A Pathophysiologic Approach Seven Edition.New York. Mc Graw Hill.

[6] Dyah, Ria Istamining.2014. Analisis Biaya Terapi Pasien Diabetes Melitus Rawat Inap. Jurnal Manajemen dan Pelayanan Farmasi Vol.4 No.1

[7] Katzung, Betram G, 2010, Farmakologi dasar dan Klinik, Edisi 10, EGC, Jakarta.

[8] Rismayhanti, Cerika.2010.Terapi Insulin Sebagai Alternatif Pengobatan Bagi Penderita Diabetes. Medikora Vol.VI No.2:29-36.
[9] Pramestiningtyas, E., S. Budi, P., Wiratmo, Holidah, D., Fajrin, F.A. 2014. Analisis Eektivitas Biaya Berasarkan Nilai ACER Penggunaan Insulin Dibandingkan Kombinasi Insulin-Metformin Pada Pasien Diabetes Melitus Tipe 2 Instalasi Rawat Inap RSD dr.Soebandi Jember Periode 2012. Artikel Ilmiah Hasil Penelitian Mahasiswa 2012.

[10]Dinaryanti, P., Fudholi, A., Andayani, T.M. 2012. Analisis Biaya dan Efektivitas Terapi Pasien Diabetes Melitus Tipe 2 Rawat Jalan di RSUD Sleman Yogyakarta. Jurnal Manajemen dan Pelayanan Farmasi. Vol 2 No.1.

[11]Riset Kesehatan Dasar (Riskesdas). 2018. Pedoman Pewawancara Petugas Pengumpul Data. Jakarta: Badan Litbangkes, Depkes RI

[12]Mursalin \& Soewondo, Prastuti. 2016. Analisis Estimasi Biaya Langsung Medis Penderita Rawat Jalan Diabetes Melitus Tipe 2 di RSUD Dr.Abdul Aziz Singkawang Tahun 2013. Jurnal Ekonomi Kesehatan Indonesia. 